\title{
Active Interrogation Safety: DT Generator Dosimetry Measurements
}

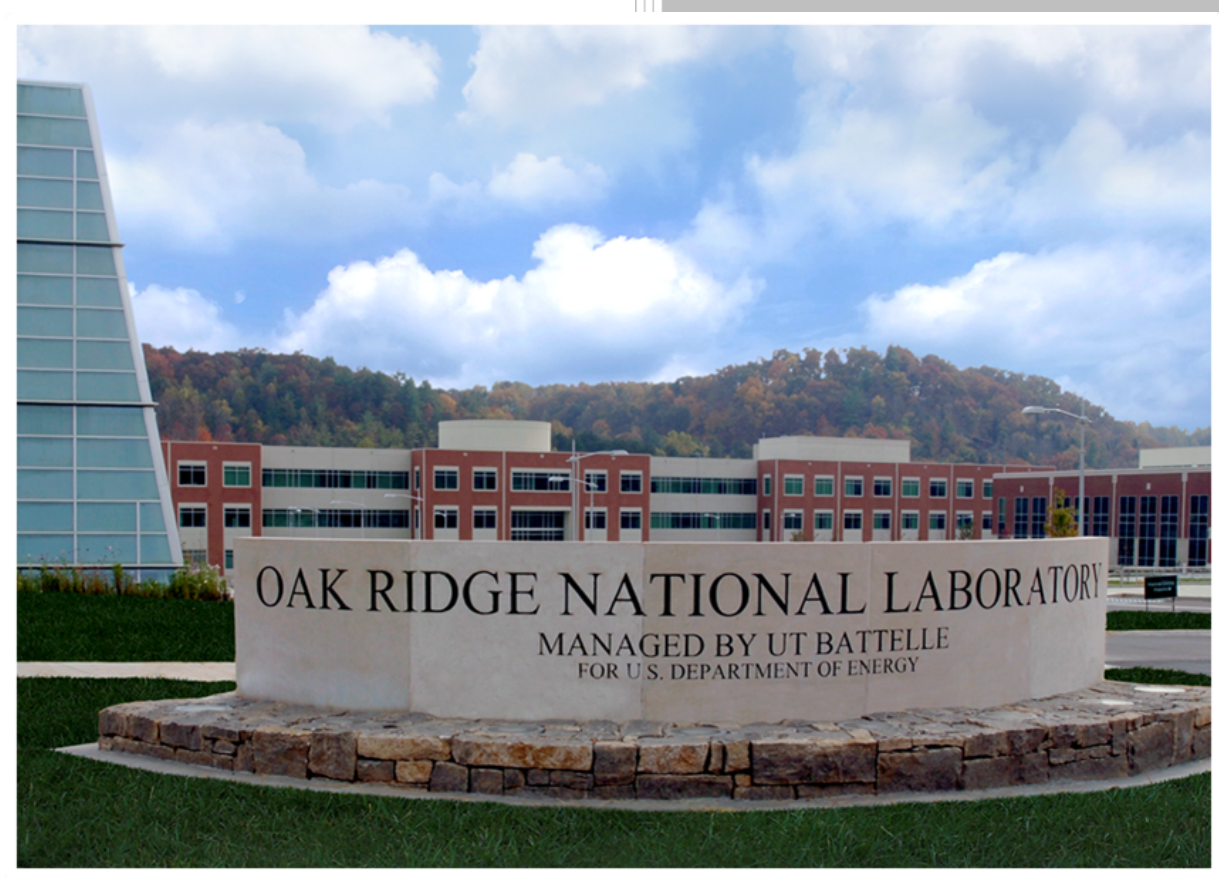

Approved for public release. Distribution is unlimited.
James A. Mullens

Debora Austin

John T. Mihalczo

December 2014 


\section{DOCUMENT AVAILABILITY}

Reports produced after January 1, 1996, are generally available free via US Department of Energy (DOE) SciTech Connect.

Website http://www.osti.gov/scitech/

Reports produced before January 1, 1996, may be purchased by members of the public from the following source:

National Technical Information Service

5285 Port Royal Road

Springfield, VA 22161

Telephone 703-605-6000 (1-800-553-6847)

TDD 703-487-4639

Fax 703-605-6900

E-mail info@ntis.gov

Website http://www.ntis.gov/help/ordermethods.aspx

Reports are available to DOE employees, DOE contractors, Energy Technology Data Exchange representatives, and

International Nuclear Information System representatives from the following source:

Office of Scientific and Technical Information

PO Box 62

Oak Ridge, TN 37831

Telephone 865-576-8401

Fax 865-576-5728

E-mail reports@osti.gov

Website http://www.osti.gov/contact.html

This report was prepared as an account of work sponsored by an agency of the United States Government. Neither the United States Government nor any agency thereof, nor any of their employees, makes any warranty, express or implied, or assumes any legal liability or responsibility for the accuracy, completeness, or usefulness of any information, apparatus, product, or process disclosed, or represents that its use would not infringe privately owned rights. Reference herein to any specific commercial product, process, or service by trade name, trademark, manufacturer, or otherwise, does not necessarily constitute or imply its endorsement, recommendation, or favoring by the United States Government or any agency thereof. The views and opinions of authors expressed herein do not necessarily state or reflect those of the United States Government or any agency thereof. 
ORNL/LTR-2014/669

Nuclear Security and Isotope Technology Division

Active Interrogation Safety: DT Generator Dosimetry Measurements

\author{
James A. Mullens \\ Debora Austin \\ John T. Mihalczo
}

Date Published: December 2014

\author{
Prepared by \\ OAK RIDGE NATIONAL LABORATORY \\ Oak Ridge, Tennessee 37831-6283 \\ managed by \\ UT-BATTELLE, LLC \\ for the \\ US DEPARTMENT OF ENERGY \\ under contract DE-AC05-00OR22725
}




\section{CONTENTS}

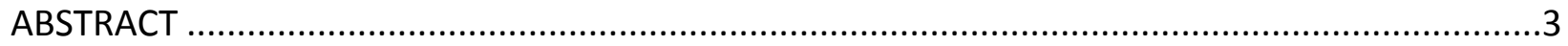

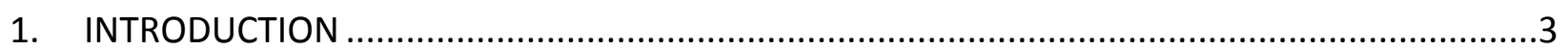

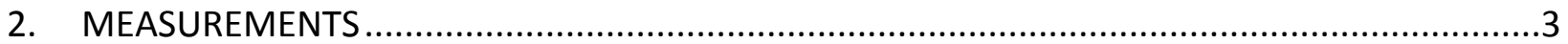

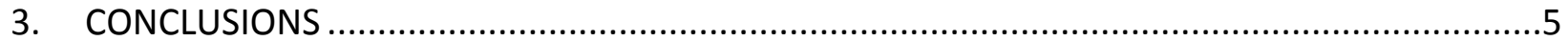

Page 2 of 6 


\title{
ACTIVE INTERROGATION SAFETY: DT GENERATOR DOSIMETRY MEASUREMENTS
}

\begin{abstract}
The use of low neutron output $\left(<1 \times 10^{8}\right.$ neutrons per second) deuterium-tritium (DT) generators for active interrogation results in a low-dose neutron exposure of personnel. The dose is sufficiently low to personnel using an associate particle imaging (API) DT neutron generator that time and distance is sufficient to minimize exposure to personnel. This type of source can be turned off when the generator has to be relocated appropriately for use. Neutron and gamma dosimetry measurements were performed at Oak Ridge National Laboratory for a generator operating at $5 \times 10^{7}$ neutrons per second. The gamma dose was almost negligible compared to the neutron dose. The measured neutron dose at 8 meters was 1.4 mrem per hour. This agrees well with measurements of the ING-27 generator at the All Russian Institute of Automatics (VNIIA) in Moscow where the neutron dose was measured to be 1.5 mrem per hour at 10 meters. Because there is no need to be close to the generator during operation, normal ALARA practice would result in negligible doses to operators compared to the natural background dose (e.g., 350 mrem in Tennessee).
\end{abstract}

\section{INTRODUCTION}

When using neutron sources there is always a concern about neutron dose to personnel. The neutron and gamma dose was recently measured as a function of distance from an associated particle imaging (API) deuterium-tritium (DT) neutron generator operating at a neutron output of $5 \times 10^{7}$ neutrons per second. This type and intensity of a neutron source is used for fastneutron imaging ${ }^{1}$ for the Nuclear Material Identification System (NMIS) ${ }^{2}$ and its fieldable version (FNMIS) ${ }^{3}$ being developed for the US DOE Office of Nuclear Verification (ONV) and others by the US DOE Office of Defense Nonproliferation Research and Development (NA-22).

\section{MEASUREMENTS}

For these measurements, the neutron and gamma dose was measured up to 8 meters away from a Thermo-Fisher API-120 DT neutron generator operating at $5 \times 10^{7}$ neutrons per second. The space between the neutron and gamma dosimeters was unobstructed, and the generator and measuring equipment were 90 centimeters above the floor. A photograph of the generator and the dosimeters is shown in Fig. 1. 


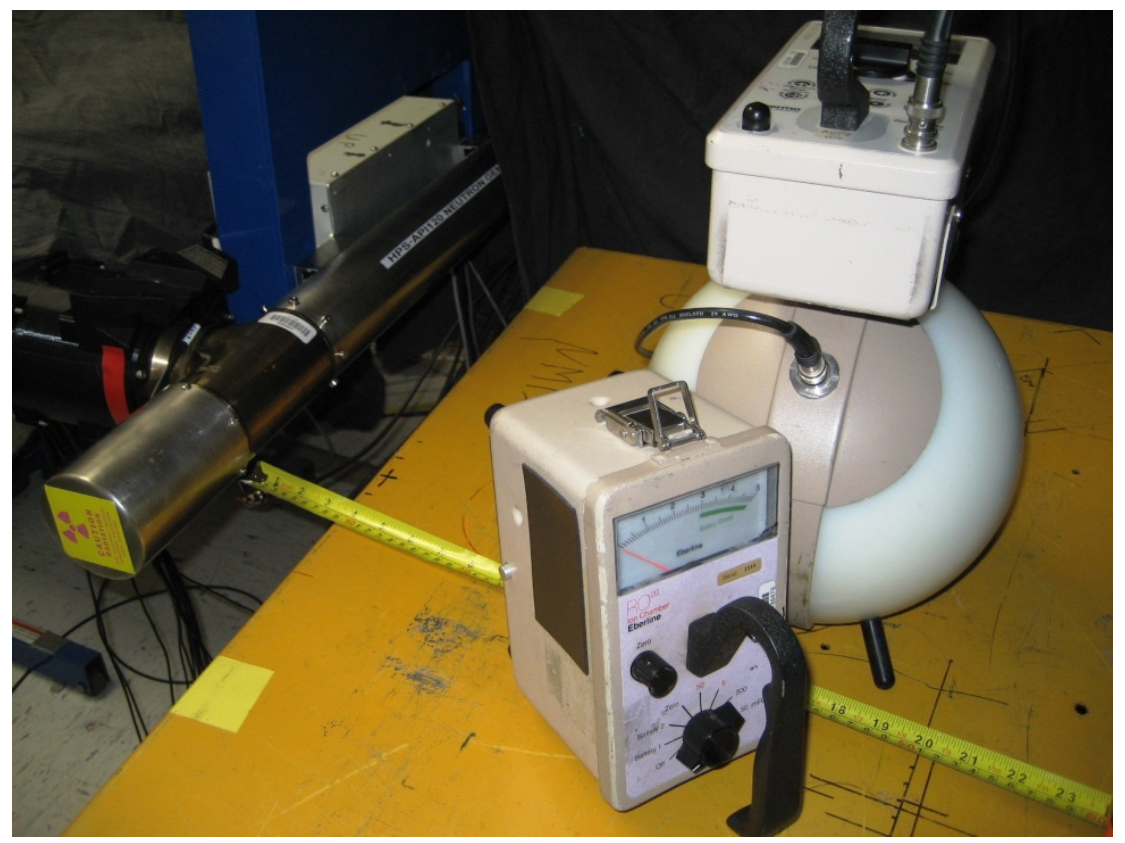

Fig. 1. The D-T neutron generator (left) with the Eberline RO20 lon Chamber gamma dosimeter (center front), and REM Ball Eberline ASP2e by Thermo Electron Corporation neutron dosimeter (right rear).

The measured dose as a function of distance out to 8 meters is given in Table 1.

Table 1. Measured dose as a function of distance from a Thermo-Fisher API-120 DT generator

\begin{tabular}{|r|r|r|r|}
\hline \multirow{2}{*}{$\begin{array}{c}\text { Distance } \\
\text { (cm) }\end{array}$} & \multicolumn{3}{|c|}{ Dose Rate (mrem/hour) } \\
\cline { 2 - 4 } & Neutron & Gamma & Total \\
\hline 30 & 250 & 35 & 285 \\
\hline 100 & 45 & 10 & 55 \\
\hline 200 & 12 & 1 & 13 \\
\hline 400 & 5 & 0.3 & 5.3 \\
\hline 600 & 2.5 & 0.1 & 2.6 \\
\hline 800 & 1.4 & 0.1 & 1.5 \\
\hline
\end{tabular}

The total dose rate is plotted in Fig. $\mathbf{2}$ and fitted to the equation shown in the insert, where $y$ is the dose rate $(\mathrm{mrem} / \mathrm{hr})$ and $\mathrm{x}$ is the distance to the generator $(\mathrm{cm})$.

A typical distance for location of personnel during operation of the generator operating at $5 \times 10^{7}$ neutrons per second is 8 meters. In addition, personnel could be located such that the interrogated object is between the generator and the personnel, thus shielding personnel from the generator and reducing their neutron dose considerably. 


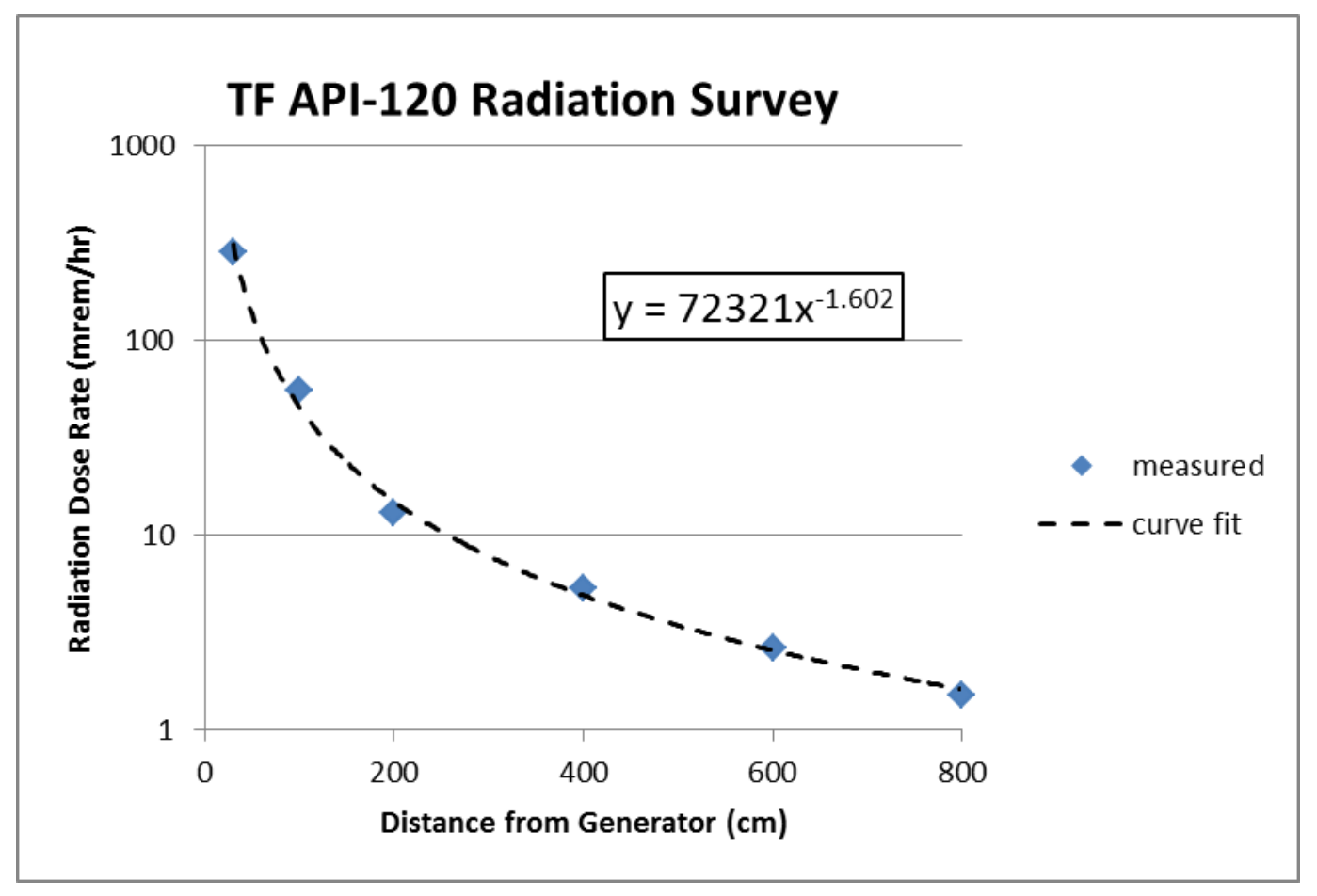

Fig. 2. Total dose as a function of distance from a DT generator operation at $5 \times 10^{7}$ neutrons per second.

\section{CONCLUSIONS}

Utilization of an API-DT neutron generator for fast-neutron imaging can result in very low radiation exposure rates to the operators. Dose rates are about $2 \mathrm{mrem}$ per hour at a reasonable standoff distance, so normal ALARA practice would result in negligible doses to operators compared to the natural background dose (e.g., $350 \mathrm{mrem}$ in Tennessee).

The generator's effect on the interrogated object is assessed in another report ${ }^{4}$.

\section{REFERENCES}

1. J. T. Mihalczo, P.R. Bingham, M. A. Blackston, J.M. Crye, B.R. Grogan, P.A. Hausladen, S.M. McConchie, J.A. Mullens. "Fast Neutron Imaging with API DT Neutron Generators", Proceedings of the International Technical and Scientific ConferencePortable Neutron Generators and Technologies on their Bases, The All Russian Institute of Automatics (VNIIA), Moscow (Oct 2012)

2. J.T. Mihalczo, J.A. Mullens, "Nuclear Material Identification System with Imaging and Gamma Ray Spectrometry" Oak Ridge National Laboratory, ORNL/TM-2012/22 (2012) 
3. James E. Radle, et. al., "Fieldable Nuclear Material Identification System "Proceedings of the Annual INMM Meeting, Baltimore 2010 (2010)

4. John T. Mihalczo, James J Henkel, "Active Neutron Interrogation Effects in Nuclear Weapons”, Oak Ridge National Laboratory, ORNL/TM-2011/326 (Oct 2012) 